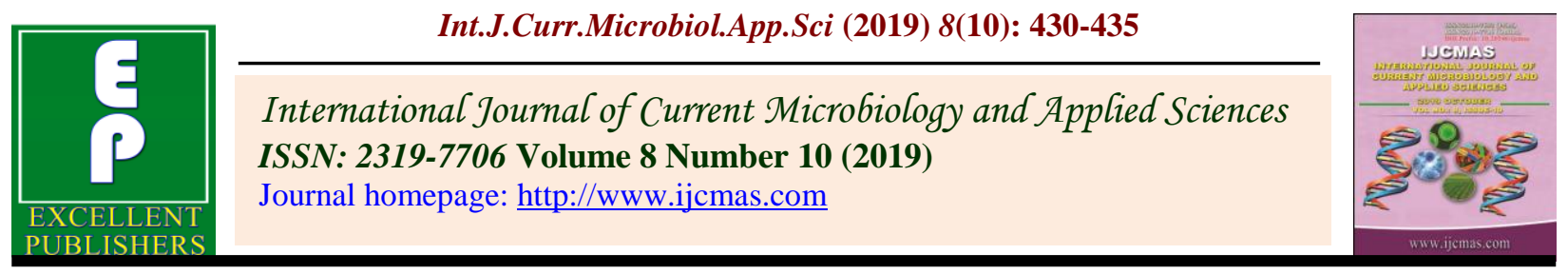

Original Research Article

https://doi.org/10.20546/ijcmas.2019.810.045

\title{
Study on Adoption of Integrated Pest Management Practices by Soybean Growers in Khandwa District of Madhya Pradesh, India
}

\author{
Shivpal Singh*, Dharmendra Yadav and Vijesh Hariyale
}

Pipliyafull, Post-Jawar, tehcil, Khandwa, Madhya Pradesh, India

*Corresponding author

\begin{tabular}{|l|}
\hline Ke y w o r d s \\
IPM, Soybean \\
growers, Adoption, \\
Chi-square test
\end{tabular}

\section{A B S T R A C T}

The present study was conducted at Pandhana block of Khandwa district Madhya Pradesh. The finding of the research revealed that Integrated Pest Management practice by soybean growers. The out of total soybean growers $47.27 \%$ had low adoption level of integrated pest management practices and only $5.46 \%$ had high adoption level of integrated pest management practices. The study also indicated the association between various attributed of soybean growers like education, annual income, scientific orientation, attitude toward IPM, knowledge of IPM, mass media exposure, extension contact were found to be 0.05 level of significance with adoption of IPM practices, Whereas age, family size, family type, land holding, area under soybean had showed that non-significant association with adoption level of soybean growers, thus the study highlighted the high adoption of integrated pest management practices by soybean growers.

\section{Introduction}

Soybean (Glycine max) is the single largest oilseed crop produced in the world of the total 310-320 million tones oilseeds produced annually. It is the most potential among grain legume crops for combating acute nutritional demand. Further its significance is also visualized with its capability to fix the atmospheric nitrogen at the rate of 85-115 $\mathrm{kg} / \mathrm{ha}$ (Alexander, 1997) besides high yield potential (20 to $25 \mathrm{q} / \mathrm{ha}$ ). It also provides high quality protein ( $40 \%$ to $42 \%$ ), $20 \%$ cholesterol free oil and 30\% carbohydrate. Soya flour is also used in sweet, papad and similar products instead of besan. It is also found suitable for industrial use like in pharmaceutical, farming, plywood glues, asphalt cements, detergent products, paper boards and laminations, fibre board, shoe polish, textile etc. It is also found its application in Bio-Medical area like Antibiotics etc. Moreover, scientists also searching for its potential applications for not yet explored areas like eco-friendly fuel, 
nutritious food varieties etc. Amongst soybean producing countries USA stands position first while India fifth. In India soybean is cultivated in about 120.327 lac hectares area and production is about 129.832 lac metric ton (Sopa 2013). Madhya Pradesh is recognized as soybean state in our country. In Madhya Pradesh soybean is cultivated in about 108.834 lac hectares area with the production of 104.366 lac metric ton (Sopa, 2014) while in Khandwa district soybean is cultivated in 1.945 lac hectares area with the production of 2.400 lac metric tons (Sopa, 2013). The productivity of soybean is affected by many factors viz. crop genetics, resource managements and climatic factors. The losses caused by weeds, insects, diseases are $75 \%$, $15-20 \%, 10-15 \%$, respectively (James H. and J. Bittzer 2011). Integrated Pest Management (IPM) approaches have been globally accepted for achieving sustainability in agriculture and maintaining the agro-eco-system. It is more relevant due to a number of advantages like safe to environment, pesticide free food commodities, low input based crop production.

The study was conducted in Khandwa District of Madhya Pradesh state with the specific objective to study the socio-personaleconomic, communicational and psychological features of the soybean growers, to study the extent of adoption of Integrated Pest Management practices by soybean growers, to find out the association between dependent and independent variables, to find out the constraints perceived by soybean growers in adoption of Integrated Pest Management practices.

\section{Materials and Methods}

The study was conducted in Pandhana block consists of 102 villages out of which 5 villages were selected by using proportionate random sampling method. A list of farmers from selected villages who are growing soybean crop was prepared with the help of agriculture extension official working in study area.

Respondent were selected by using proportionate random sampling method to make the total sample size 110 for the primary data were collected personally by interviewed schedule.

The secondary data were collected from Department of Agriculture, the respondents were asked to give opinion about the use of recommended soybean growers practices (adoption) on three point continuum viz. complete, uncompleted and never and scores 2, 1 and 0 were assigned respectively. Extent of adoption was calculated on the basis of these scores.

Similarly the constraints faced by the soybean growers, were also recorded on the two point continuum namely Yes and No the data were analyzed using frequency, percentage, mean, chi-square test and association between dependent and independent variables.

\section{Results and Discussion}

\section{Socio-personal, economic, communicational and psychology features of the soybean growers}

The data revealed that majority of respondent $(60 \%)$ were in middle age followed by young $(33 \%)$ and old age $(11 \%)$ category (Table 1$)$, as old age farmers have almost fixed behavior patterns, so middle aged and especially young farmers must be targeted for imparting in soybean crop the respondents were having up to primary level (31.82) of education followed by illiterate level (24.55), followed by high school level (10.90), followed by college level (5.45) and higher secondary school (3.64\%) level of education. The respondent were majority of soybean growers $(42.73 \%)$ belong 
to medium family type, whereas maximum soybean growers $(50.91 \%)$ nuclear type family. The maximum number of soybean growers $(57.27 \%)$ revealed that having medium annual income range between $1,83,001$ to $3,66,000$, whereas maximum soybean growers $(47.28 \%)$ were found having medium farmers. The table also revealed that the maximum number of soybean growers (39.09\%) were found 2.01 to 4 hac.

Area under soybean crop. The finding regarding farm power revealed that the maximum numbers of soybean grower $(57.27 \%)$ were having low farm power.

Economic motivation of soybean growers was higher $(48.18 \%)$ in medium and high economic motivation. The higher percentage of soybean growers $(73.63 \%)$ had medium scientific orientation whereas majority of the soybean growers $(64.55 \%)$ had medium attitude towards IPM practices.

Results also showed that the maximum soybean growers $(52.73 \%)$ had medium knowledge of IPM practices. About (64.54\%) soybean growers were having medium mass media exposure. The maximum number of soybean growers $(59.09 \%)$ was found low extension contact the present findings are inconformity with other reporters' viz. verma (2009), Mandloi (2007), Sharma (2007), Pandey (1998)

\section{Adoption of IPM practices by soybean growers}

Adoption of IPM practices by the soybean growers. The study revealed that maximum number $(47.27 \%)$ of soybean growers had low and medium adoption of integrated pest management practices. It was also observed that only $(5.46 \%)$ had high adoption of IPM practices (Table 2).

Association between attributes of the soybean growers and their extent of adoption level of IPM practices

Association between attributes of the soybean growers and their extent of adoption level of IPM practices like education, annual income, scientific orientation, attitude towards IPM, knowledge of IPM, mass media exposure, extension contact were found to have significant association with adoption of soybean growers (Table 3). Whereas age, family type, land holding, area under soybean crop had showed that non-significant association with adoption level of soybean growers. Most of the soybean growers (60\%) belonged to middle age group (36 to 55 years), whereas in case of education level of soybean growers $(31.82 \%)$ had educated up to primary school and maximum belonged to medium family size and maximum (50.91\%) nuclear family type. The majority of respondents were having medium annual income $(1,83,001$ to $3,66,000 \mathrm{Rs})$.

The study revealed that, the higher percentage of soybean growers (47.28\%) had medium size group of land holding whereas maximum number $(39.09 \%)$ of soybean growers belong to 2.01 to 4 hac. area under soybean crop and low number of farm power (57.27\%). The study further depicted that, the majority of soybean growers had medium and high economic motivation $(48.18 \%)$ and scientific orientation (73.63\%). In case of attitude towards IPM practices (64.55\%), knowledge of IPM (52.73\%), and mass media exposure $(64.54 \%)$ of soybean growers having medium. The extension contact had low (59.09\%) of soybean growers. 
Table.1 Socio-personal, economic, communicational and psychology features of the soybean growers

\begin{tabular}{|c|c|c|c|}
\hline Variables & Characteristics & Frequency & Percentage \\
\hline Age & $\begin{array}{c}\text { Young ( Up to } 35 \text { years) } \\
\text { Middle ( } 36 \text { to } 55 \text { years) Old } \\
\text { ( Above } 55 \text { years) }\end{array}$ & $\begin{array}{l}33 \\
66 \\
11\end{array}$ & $\begin{array}{l}30.00 \\
60.00 \\
10.00\end{array}$ \\
\hline Education & $\begin{array}{c}\text { Illiterate } \\
\text { Up to Primary school Middle } \\
\text { school } \\
\text { High school } \\
\text { Higher secondary } \\
\text { College }\end{array}$ & $\begin{array}{l}27 \\
35 \\
26 \\
12 \\
04 \\
06\end{array}$ & $\begin{array}{c}24.55 \\
31.82 \\
23.64 \\
10.90 \\
3.64 \\
5.45\end{array}$ \\
\hline Family size & $\begin{array}{l}\text { Small family size Medium } \\
\text { family size Large family size }\end{array}$ & $\begin{array}{l}42 \\
47 \\
21\end{array}$ & $\begin{array}{l}38.18 \\
42.73 \\
19.09\end{array}$ \\
\hline Family type & $\begin{array}{c}\text { Nuclear } \\
\text { Joint }\end{array}$ & $\begin{array}{l}56 \\
54\end{array}$ & $\begin{array}{l}50.91 \\
49.09\end{array}$ \\
\hline Annual income & $\begin{array}{l}\text { Low annual income Medium } \\
\text { annual income High annual } \\
\text { income }\end{array}$ & $\begin{array}{l}34 \\
63 \\
13\end{array}$ & $\begin{array}{r}30.91 \\
57.27 \\
11.82\end{array}$ \\
\hline Land holding & $\begin{array}{l}\text { Marginal farmers (up to } 1 \text { ha.) } \\
\text { Small farmers ( } 1.01 \text { to } 2 \text { ha.) } \\
\text { Medium farmers ( } 2.01 \text { to } 4 \\
\text { ha) }\end{array}$ & $\begin{array}{l}14 \\
12 \\
52 \\
32\end{array}$ & $\begin{array}{l}12.73 \\
10.90 \\
47.28 \\
29.09\end{array}$ \\
\hline $\begin{array}{l}\text { Area under soybean } \\
\text { crop }\end{array}$ & $\begin{array}{l}\text { Up to } 1 \text { ha. } \\
1.01 \text { to } 2 \text { ha. } \\
2.01 \text { to } 4 \text { ha. } \\
\text { Above } 4 \text { ha. }\end{array}$ & $\begin{array}{l}35 \\
26 \\
43 \\
06\end{array}$ & $\begin{array}{c}31.82 \\
23.64 \\
39.09 \\
5.45\end{array}$ \\
\hline Farm power & $\begin{array}{l}\text { Low farm power } \\
\text { Medium farm power } \\
\text { High farm power }\end{array}$ & $\begin{array}{l}63 \\
42 \\
05\end{array}$ & $\begin{array}{c}57.27 \\
38.18 \\
4.55\end{array}$ \\
\hline Economic motivation & $\begin{array}{l}\text { Low } \\
\text { Medium } \\
\text { High }\end{array}$ & $\begin{array}{l}04 \\
53 \\
53\end{array}$ & $\begin{array}{c}3.64 \\
48.18 \\
48.18\end{array}$ \\
\hline Scientific orientation & $\begin{array}{l}\text { Low } \\
\text { Medium } \\
\text { High }\end{array}$ & $\begin{array}{l}03 \\
81 \\
26\end{array}$ & $\begin{array}{c}2.73 \\
73.63 \\
23.64\end{array}$ \\
\hline Attitude toward IPM & $\begin{array}{l}\text { Low } \\
\text { Medium } \\
\text { High }\end{array}$ & $\begin{array}{l}08 \\
71 \\
31\end{array}$ & $\begin{array}{l}07.27 \\
64.55 \\
28.18\end{array}$ \\
\hline Knowledge of IPM & $\begin{array}{l}\text { Low } \\
\text { Medium } \\
\text { High }\end{array}$ & $\begin{array}{l}32 \\
58 \\
20\end{array}$ & $\begin{array}{l}29.09 \\
52.73 \\
18.18\end{array}$ \\
\hline Mass media exposure & $\begin{array}{l}\text { Low } \\
\text { Medium } \\
\text { High }\end{array}$ & $\begin{array}{l}38 \\
71 \\
01\end{array}$ & $\begin{array}{l}34.55 \\
64.54 \\
00.91\end{array}$ \\
\hline Extension contact & $\begin{array}{l}\text { Low } \\
\text { Medium } \\
\text { High }\end{array}$ & $\begin{array}{l}65 \\
45 \\
00\end{array}$ & $\begin{array}{l}59.09 \\
40.91 \\
00.00\end{array}$ \\
\hline
\end{tabular}


Table.2 Adoption of IPM practices by soybean growers

\begin{tabular}{|c|c|c|c|}
\hline S.No. & Categories & Frequency & Percentage \\
\hline $\mathbf{1 .}$ & Low & 52 & $\mathbf{4 7 . 2 7}$ \\
\hline $\mathbf{2 .}$ & Medium & 52 & $\mathbf{4 7 . 2 7}$ \\
\hline $\mathbf{3 .}$ & High & 06 & $\mathbf{0 5 . 4 6}$ \\
\hline & Total & $\mathbf{1 1 0}$ & $\mathbf{1 0 0 . 0 0}$ \\
\hline
\end{tabular}

Table.3 Association between attributes of the soybean growers and their extent of adoption level of IPM practices

\begin{tabular}{|c|c|c|}
\hline Variable & Chi-square value & D.F \\
\hline Age & 1.46 & 1 \\
\hline Education & 7.89 & 3 \\
\hline Family size & 2.51 & 2 \\
\hline Family type & 2.30 & 1 \\
\hline Annual income & 5.30 & 1 \\
\hline Land holding & 2.88 & 2 \\
\hline Area under soybean crop & 1.19 & 2 \\
\hline Farm power & 12.84 & 1 \\
\hline Economic motivation & 6.61 & 1 \\
\hline Scientific orientation & 7.99 & 1 \\
\hline Attitude toward IPM & 15.10 & 1 \\
\hline Knowledge of IPM & 24.92 & 1 \\
\hline Mass media exposure & 16.24 & 1 \\
\hline Extension contact & 6.82 & 1 \\
\hline
\end{tabular}

\section{References}

Alexander M. 1997. Pulse crop. Oxford and IDH publishing Co. Pvt. Ltd, pp-55.

James $\mathrm{H}$ and Bitzer J. 2011. Production in kentucky part iv, weed, disease and insect control AGR-131 issued 4-88.

Mandloi RS. 2007. A comparative study on adoption of soybean production technology in high and low productive block of Dhar district (M.P.). M.Sc. (Ag.) Thesis, JNKVV, Jabalpur.

Pande AK, Panwar MP and Sanoria YC. 1998. Adoption of soybean production technology among farmers. Madhya Journal of Ext. Edu. 1(1): 38-42
Sharma Rohit 2007. A study of knowledge and adoption behaviour of soybean growers in Sehore district of M.P. M.Sc. (Ag.) Thesis, JNKVV, Jabalpur.

Soybean Production Association. 2013. Area and production of soybean in IndiaKharif 2013 survey conducted by Indore with effect from September 1527.

Verma L. 2009. "A study on adoption of integrated pest management practices by the cotton growers in Khandwa District (M.P.)" M.Sc. (Ag.) Thesis, J.N.K.V.V., Jabalpur 


\section{How to cite this article:}

Shivpal Singh, Dharmendra Yadav and Vijesh Hariyale. 2019. Study on Adoption of Integrated Pest Management Practices by Soybean Growers in Khandwa District of Madhya Pradesh. Int.J.Curr.Microbiol.App.Sci. 8(10): 430-435. doi: https://doi.org/10.20546/ijcmas.2019.810.045 